\title{
КОНЦЕПТУ АЛНЕ ВРЕДНОСТИ ЛЕКСЕМЕ ДРВО И ЊЕНИХ ДЕРИВАТА У СРПСКОМ ЈЕЗИКУ
}

На основу лексичког значења лексеме дрво и њених деривата утврђују се појмовни домени којима посматране јединице припадају с обзиром на њихове значењске реализације. Будући да је лексема дрво вишезначна, њено семантичко-деривационо гнездо је развијено и обухвата више од две стотине деривата с потврдом у РМС и РСАНУ. Компоненцијалном анализом утврђене су компоненте значења из примарне реализације мотивног појма које су у функцији индуктора даљих деривата. Анализа показује да су деривати различитог степена, различите творбене структуре, а да се на основу значења уклапају у девет појмовних домена са већим бројем лексема и у пет појмовних домена са по једним представником.

Кључне речи: лексема дрво, деривати, концептуализација, појмовни домени, српски језик.

\section{1. УВОД}

У овом истраживању утврђују се појмовни домени који се у српском језику концептуализују посредством лексеме дрво и њених деривата. Појмовни домени су општијег карактера и представљају вишу семантичку категорију у односу на појединачно лексичко значење; чине их скуп лексема које деле важна категоријална обележја (архисему и диференцијалне семе високог ранга) из којих произилази њихова концептуална сродност. Дакле, на основу концептуалне вредности сагледана је припадност деривата одређеним појмовним доменима. Тако се у исти домен укључују јединице које се тичу истог концепта, без обзира на њихове морфолошке карактеристике.

Семантичке интерпретације одабраног предмета истраживања засноване су на елементима концептуалне анализе, уз примену метода компоненцијалне анализе. Наиме, везу између појмовних домена и

\footnotetext{
*gordanastasni@ff.uns.ac.rs
} 
семантичких промена мотивног појма и његових деривата могуће је боље сагледати посредством компоненцијалне анализе. „Разлагање семантичког садржаја лексема на његове семе омогућиће јасније уочавање принципа по којима се обележја одређеног појма хијерархизују у свести говорника индукујући нове садржаје" (Штрбац - Штасни, 2017: 9). Лексеме имају сложену семантичку структуру која је грађена од компонената које се различито комбинују при формирању значења друге лексеме. Међутим, нису све семантичке компоненте подједнако језички релевантне, без обзира на то што су све оне носиоци одређених информација (Lyons, 1995: 108; Leech, 1983: 89). Само неке од њих утичу на стварање нових значења и/или нових лексема.

Компоненцијалном анализом семантичког садржаја лексеме дрво утврдиће се компонете значења које су у функцији индуктора како нових значења у оквиру њене семантичке структуре тако и у творби нових лексема које су с њом у семантичко-деривационој вези.

\section{2. СЕМАНТИЧКА СТРУКТУРА ЛЕКСЕМЕ ДРВО}

Лексема дрво има полисемантичну структуру. РМС бележи три реализације. Примарно значење садржи појмовну вредност именованог ентитета - архисему (биљка), са квалификаторима који представљају диференцијалне семантичке компоненте високог ранга - сема трајања (дугогодишња), затим сема састава, делова дрвета (стабло, гране, корен) 'дугогодишња биљка са стаблом, гранама и корењем'. Секундарно значење 'сасечена дрва' засновано је на синегдохи (иелина - део односно дрво - део дрвета, комад дрвета), а фигуративно значење 'ударац дрвеним штапом' почива на метонимији оствареној по обрасцу биљка $\rightarrow$ предмет направљен од ње $\rightarrow$ резултат радње или радња која се изводи помоћу тог предмета.

У РСАНУ ова лексема има пет семантичких реализација. Лексикографска интерпретација примарног значења обухвата следеће елементе: архисему и диференцијалне семе високог ранга квалитативног типа: вишегодишња, висока, чврсте грађе, уз навођење партонима именованог ентитета. Посебно се у дефинцији лексеме дрво издвајају компоненте које се односе на партоним стабло (кореном причврићено за земьу, у средњем делу голо, при врху обрасло гранама и лишћем). Фигуративно подзначење ‘породица, лоза, стабло' индуковано је метафоричном асоцијацијом која је заснована на компоненти изгледа именованог ентитета. 
Прва секундарна реализација 'исечено, исцепано комађе стабла и грана дрвета које се употребљава за огрев’ углавном је подударна с оном датом у РМС, али се треће по реду значење 'најчвршћи део стабла и грана, између сржи и лике, који се као материјал употребљава у занатству, индустрији, грађевинарству и др.' не наводи у РМС. Оно је настало под утицајем синегдохе, при чему се део одређене целине именује називом саме целине.

И четврто значење, обележено као покрајинизам, није укључено у лексикографску интерпретацију ове лексеме у РМС. Оно је засновано на метонимијском преносу по моделу материја $\rightarrow$ предмет израђен од те материје и гласи 'назив који се ради лакшег, бржег казивања даје од случаја до случаја разним дрвеним предметима (обично једноставним) и њиховим деловима'. Међутим, подзначење кодирано као фигуративно 'ударац дрвеним штапом’, у РМС се наводи као самостална секундарна реализација (трећа по реду).

Последње значење у низу са својим подзначењима такође није уврштено у РМС. Све реализације су покрајинизми и настале су углавном под утицајем метонимије (материја $\rightarrow$ предмет/део предмета израђен од те материје) а. 'брод, лађа'; б. мн. (дрвета) 'даске што се стављају изнад мртваца кад се леш без ковчега положи у раку'; в. мн. 'вешала'.

Семантички садржај мотивне речи одражава се на њене деривационе могућности. Семантичко-деривационо гнездо лексеме дрво садржи више од сто деривата различитих морфолошких и деривационо-семантичких карактеристика (на основу података из РМС). С намером да се системски и што потпуније сагледају семантичко-деривационе способности лексеме $\partial р в о$, грађа је допуњена јединицама ексцерпираним из РСАНУ (још око стотину деривата). Углавном су то лексеме територијално маркиране као покрајинизми, али има и архаизама, индивидуалних творевина, кованица, необичних образовања и сл. ${ }^{1}$

\footnotetext{
${ }^{1}$ Нису узети у обзир деривати изведени од дијалекатског облика древо (дријево) покр. 1. 'дрво (које расте)'; 2. фиг. заст. 'брод, лађа' будући да овај покрајинизам нема развијену деривациону мрежу. У РМС је забележена само збирна именица древад, а у РСАНУ и древаи, древен, древенда, древеће, древје, древодеља, древие.
} 


\section{3. ПОЈМОВНИ ДОМЕНИ}

3.1. Лексемом дрво мотивисана је творба деривата који се својом семантиком не удаљавају од мотивног појма. У првом реду то су збирне именице, граматичка образовања, дрвеће и дрвље и покрајинизми дрвад, дрвљад, дрвљеће, дрвеље (у народној песми). На творбеном плану посматране јединице су деривати првога степена изведени суфиксима карактеристичним за парадигму којој припадају (-овина; -ећи; -ни, -ов; -ad, -ље), док суфикс -иште има пак несистемску употребу у комбинацији с основом именице. ${ }^{2}$

Примарним значењем лексема дрвовина успоставља синонимну везу с примарним значењем мотивне речи, а подзначења 'најчвршћи део стабла'; б. 'дрвенасто, одрвенело ткиво биљке уопште' такође је одређују као елеменат овога скупа својом партонимском компонентом, ${ }^{3}$ коме припада и дериват дрвљика индив. 'стабло, дрво' и дрвиште 'дрва за огрев'. Партоними су засновани на односу део - иелина, који је типичан за синегдоху. Слично је и са лексемом дрвенчииа, која је у РСАНУ означена као необична и са значењем 'одрвенела ћелија биљке'.

3.2. ЧОВЕК. С мотивном речју дрво најпродуктивнија су именичка образовања с човеком као денотатом. Овом појмовном домену припадају агентивне и атрибутивне именице. Са становишта творбе речи то су доминантно сложеничке форме, ретко изведенице.

Изведеница дрвар има два значења, оба су агентивног типа: 1. 'човек који сече или довози дрва из шуме, дрвосеча'; 2. 'трговац дрвима'. Она је у основи другостепених моционих образовања дрварка и дрварииа 'женска особа која сече или скупља дрва у шуми или која продаје дрва'. Оба ова деривата имају веома развијену семантичку структуру. ${ }^{4}$ Трансформациони

${ }^{2}$ И. Клајн наводи да „значење дршке или ручице на некој алатки, као у косиште, c(j)екириште, грабљиште, данас углавном спада у архаизме” (Клајн, 2003: 126). Овај податак наводимо јер је употреба суфикса -иште у комбинацији с именичким основама типична и системска у творби именица са значењем места, аугментатива и пејоратива. Све остала значења и комбинације су периферне, нетипичне.

${ }^{3}$ На основу секундарне реализације ‘предмети израђени од дрвета, дрвенарија' (покр.) овај дериват се уклапа у продуктиван домен који чине називи предмета направљених од дрвета.

4 Понављањем творбеног модела развија се семантика деривата дрварица 2.а. 'лађа којом се превозе дрва'; б. 'мазга на којој се преносе дрва', као и деривата дрварка 2. ‘корпа за преношење, превоз дрва' и 3. мн. покр. ‘кола за превоз дрва'. У РМС значење 
модел који одговара сложеницама агентивног типа изражава се формулом онај који 'значење глагола у основи' дрво. Основа мотивне речи дрво представља прву сложеничку компоненту, која у парафрази има функцију објекта уз транзитивне глаголе - дељати, красти, носити, сећи, продавати, трговати, цепати, резати, стругати. Сложенице овог семантичког типа настале су сложено-суфиксалном творбом по моделу Ио + o + Го + суфикс. Међу њима су заступљени варијантни облици условљени употребом конкурентних суфикса који су типични у деривацији агентивних именица. Најпродуктивнији је суфикс -(a)u, који се појављује у свим конкурентним варијантама, а алтернативни суфикси су: -ф и - $a$; -л( $a) u,-u щ,-a p .^{5}$

Лексеме дрворезац и дрворезач могу се двојако тумачити: а) као сложенице настале по истом моделу или б) као деривати мотивисани сложеницом дрворез, са парафразом онај који израђује дрворез.. 6 Другачијег сложеничког типа су лексеме дрворезбар и дрвостругар. Њихова друга сложеничка компонента функционише као самостална реч, те им одговара модел Ио + о + И.

Са семантичког становишта овим сложеницама се денотира особа која се бави одређеним занатом или послом, при чему лексема дрво представља објекат манипулације, а семантика глагола открива облик манипулације. Поједини глаголи најчешће успостављају рекцијску везу с лексемом дрво (дељати, резбарити, иелати), док други имају знатно шири колокациони потенцијал (красти, носити, резати, сећи, трговати) и често граде обимне

3. зоол. 'врста осе која леже јаја у стаблу бора или јеле' мотивисано лексемом дрво, која у дериват уноси локационо значење.

5 Конкурентни суфикси се јављају у следећим јединицама: - $\phi,-a,-л(a) u$ и -(a)u (дрводељ,дрводеља, дрводелац и дрводељац, с тим што се дериват дрводељаи може довести у деривационо-семантичку везу са сложеницом дрводеља, и у том случају сматра се изведеницом с основом сложене речи); -(a)u и -ица (дрвокрадац и дрвокрадица); -ар и -(а)и (дрворезар и дрворезач); -, , -а и -(а)ч (дрвосек, дрвосеча и дрвосечаи).

6 И. Клајн лексему дрворезац посматра у оквиру низа који чине сложенице с глаголском компонентом резати (стаклорезаи, печаторезац, каменорезаи) (Клајн, 2002: 57), али на другом месту, тумачећи сложенице изведене суфиксом -ница којима се углавном означавају просторије за обављање заната ,за које се иначе употребљава суфикс -аи”" даје и пример дрворезнища, а као додатну информацију у загради наводи: „уп.дрворез-аи” (Клајн, 2002: 62). 
деривационе низове. ${ }^{7}$ Овој групи припада и лексема дрвокрадищуа, у којој коегзистира агентивно и атрибутивно значење.

\begin{tabular}{|c|c|c|}
\hline $\begin{array}{l}\text { Активна } \\
\text { компонента из } \\
\text { семантичког } \\
\text { садржаја лексеме } \\
\text { дрво }\end{array}$ & Семантички модел & Добијено именовање \\
\hline учешће у обради & $\begin{array}{l}\text { 'онај који сече или } \\
\text { обрађује дрво и користи } \\
\text { га у различите сврхе' }\end{array}$ & $\begin{array}{l}\text { дрвар, дрварица, дрварка, дрводељ } \\
\text { (дрводјељ), дрводеља (дрводјеља), } \\
\text { дрводелац (дрводјелац), дрводељац } \\
\text { (дрводјељац), дрвенџија, дрворезар, } \\
\text { дрворезац, дрворезач, дрворезбар, } \\
\text { дрвоноша, дрвосек (дрвосјек), } \\
\text { дрвосеча (дрвосјеча), дрвосечац } \\
\text { (дрвосјечац), дрвостругар, } \\
\text { дрвотржац, дрвопродавац, } \\
\text { дрвоцепа (дрвоцјепа), дрвоцепка } \\
\text { (дрвоцјепка) }\end{array}$ \\
\hline
\end{tabular}

Атрибутивним именицама дрвендек, дрвендека и дрвендупа означена је особа према физичким особинама 'неспретан, неокретан, крут човек', при чему се из појмовног садржаја лексеме дрво односно придева дрвен преноси имплицитна компонента непокретљивост, непомичност. Међутим, ово својство може бити и карактерна особина особе која је неосетљива, али и приглупа. Оба значења настала су под утицајем метафоричне асоцијације засноване на наведеној компоненти значења мотивног придева. Њихова творбена структура садржи следеће елементе По + И односно По + Ио + -а, при чему је придевска компонента носилац квалификације, а именичким делом конкретизован је носилац својства. ${ }^{8}$ У РСАНУ проналазимо и лексему

\footnotetext{
${ }^{7}$ У том смислу глагол носити, према увиду у РМС, са суфиксом -ја учествује у творби више од 50 сложеница, које претежно означавају особу. Продуктивне су и сложенице с основом глагола красти као другом саставницом (дивокрадица, зверокрадица, кесокрадица, иепокрадица, коњокрадица, ловкрадича, људокрадица, мртвокрадица, рибокрадица, светокрадица, трешњокрадица, иумокрадица). Нижа је продуктивност сложеница с основом глагола трговати (велетржац, винотржац, коњотржац, ситнотржац).

${ }^{8}$ П. Скок (1971: 439) бележи придев дрвендедас (Космет) ‘крут, незграпан', који је и у појмовној вредности сложенице дрвендупа вулг. 'дрвендекаста женска особа'. У РМС придев дрвендекаст има значење 'који је крут, укочен, неспретан, као цепаница'.
} 
дрволомија индив. 'веома снажан човек', а њено значење произилази из значења саставница дрво и ломити, те је потпуно семантички прозирно.

И дериват другог степена дрвењак мотивисан придевом дрвен у секундарном фигуративном значењу 'укочен, безосећајан човек' остварен је као атрибутивна именица.

\begin{tabular}{lll}
\hline $\begin{array}{l}\text { Активна компонента } \\
\text { из семантичког } \\
\text { садржаја лексеме дрво }\end{array}$ & Семантички модел & Добијено именовање \\
\hline $\begin{array}{l}\text { непокретљивост, } \\
\text { непомичност, } \\
\text { чврстина }\end{array}$ & $\begin{array}{l}\text { 'који је непокретан попут } \\
\text { дрвета’ }\end{array}$ & $\begin{array}{l}\text { дрвендек, дрвендека, } \\
\text { дрвендупа }\end{array}$ \\
& $\begin{array}{l}\text { ‘који је сличан дрвету у } \\
\text { погледу испољавања } \\
\text { осећања' }\end{array}$ & дрвењак \\
& ‘који је сличан дрвету у & дрволомија \\
& & \\
\hline
\end{tabular}

Ономастичке јединице такође припадају овој групи. То су презимена: Дрваревић, Дрварек, Дрвениковић, Дрвенић, Дрвеница, Дрвениија, Дрвењак, Дрводелић, Дрводеља (име), Дрводјеља и Дрвођеља (презиме).

3.3. РАДњЕ, ДЕЛАТНОСТИ И СТАњА. Овом домену припадају глаголи којима се означава каква активност, радња коју изводи човек - првостепени дериват дрвити 1. 'намештати дрвене делове, дрвенарију (у згради)'; 2. 'слагати дрва'; 3. 'снабдевати се дрвима', 4. 'намештати, углављивати (нешто што се клима)', дериват другог степена дрварити 1. 'радити као дрвар, сећи дрва у шуми; фиг. тешко радити’; 2. ‘снабдевати кога дрвима за огрев’; 3. фиг. вулг. 'пијанчити, пијанчевати, лумповати', као и од њих изведене глаголске именице: дрварење, дрвљење.

Својим секундарним значењем сложеница дрвосеча 'сеча, обарање дрвећа у шуми; време вршења те радње', као и глаголска именица дрворезаъе уклапају се у посматрани лексички скуп. Овде припада и сложеница

Сложеница дрвендека даје и глаголски дериват настао префиксално-суфиксалном творбом удрвендечити се са значењем 'удрвенити се'.

9 Дериват дрварити могао би се интерпретирати и као дериват првог степена с обзиром на реализацију 'сећи дрва у шуми'. 
дрвокрађа 'крађа дрва'. И називи делатности које човек обавља: дрварство ${ }^{10}$ и дрводељство (дрводјељство), дрворезбарство, дрводеље (дрводијеље), дрводељина 'посао, занат дрводељин' имају исту концептуалну вредност, па и назив дисциплине дрвомерство 'дендометрија'.

\begin{tabular}{|c|c|c|}
\hline $\begin{array}{l}\text { Активна компонента } \\
\text { из семантичког } \\
\text { садржаја лексеме } \\
\text { дрво }\end{array}$ & Семантички модел & Добијено именовање \\
\hline учешће у обради & $\begin{array}{l}\text { 'обрада дрвета и употреба } \\
\text { у различите сврхе' }\end{array}$ & $\begin{array}{l}\text { дрворезање, дрварство, } \\
\text { дрводељство (дрводјељство), } \\
\text { дрводеље (дрводијеље), } \\
\text { дрводељина, дрворезбарство }\end{array}$ \\
\hline $\begin{array}{l}\text { манипулација } \\
\text { дрветом }\end{array}$ & $\begin{array}{l}\text { 'сеча, складиштење дрвета } \\
\text { и употреба у различите } \\
\text { сврхе' }\end{array}$ & $\begin{array}{l}\text { дрвити, дрвљење, дрварити, } \\
\text { дрварење, дрвосеча, дрвокрађа }\end{array}$ \\
\hline
\end{tabular}

Другу групу чине деривати којима се исказује стање или понашање човека, значење које је засновано на метафоричним асоцијацијама уз активирање компоненте чврст, непомичан - дрвендечити се 'понашати се као дрвендек, држати се круто’.

Овом појмовном домену припојени су глаголски деривати, нарочито на основу њихових секундарних реализација. Тако се глагол дрвенити 1.а. 'чинити дрвеним, дрвенастим'; - фиг. 'чинити крутим, кочити'; б. ‘доводити у стање запрепашћења, у запањеност, потиштеност и сл.', поред манипулативно-каузативног значења остварује и као глагол емоционалног стања. Са истим значењем је и регионално маркирани дериват дрвечити (се). Овом појмовном домену могли бисмо придружити и префиксирани глагол подрвенети (подрвењети) 'постати као дрво'.

Читав низ префиксираних медијалних глагола који су мотивисани другостепеним глаголским дериватом с основом придева дрвен $\rightarrow$ дрвенити се 'постајати дрвен, дрвенаст, укочен, без живота, запрепашћивати се' уклапају се у посматрани појмовни домен: задрвенити се 'постати дрвен, претворити се у дрво’, здрвенити се ‘постати дрвенаст, постати тврд као дрво’; фиг. 'укрутити се, укочити се; запањити се', одрвенити/одрвенети се (одрвењети се) 1. 'постати дрвен, дрвенаст; 2. фиг. а. 'постати непокретан, укочен, укрутити се'; б. 'постати

10 РСАНУ не бележи лексему дрварство, а њена дефиниција је у РМС 'наука о дрвету', а прикладније би било 'посао дрвара'. 
безосећајан, неосетљив, крут (у понашању и сл.)', удрвенити се 'постати као дрво, укрутити се, укочити се, здрвенити се'. Овде припада и покрајинизам, префиксално-суфиксална твореница, одрвочити се 'одрвенети (се)'.

Суфиксирани глагол дрвити се, дериват првог степена, има основно значење активности 'снабдевати се дрвима, дрварити се', а секундарно којим се означава стање 'дрвенити се', док се у његов префиксирани дериват удрвити се 'удрвенити се' у потпуности преноси садржај секундарне реализације мотивног глагола.

\begin{tabular}{lll}
\hline $\begin{array}{l}\text { Активна } \\
\text { компонента из } \\
\text { семантичког } \\
\text { садржаја лексеме } \\
\text { дрво }\end{array}$ & Семантички модел & Добијено именовање \\
\hline $\begin{array}{ll}\text { чврст, непомичан, } \\
\text { тврд }\end{array}$ & $\begin{array}{l}\text { 'добити/добијати } \\
\text { неко својство } \\
\text { дрвета’ }\end{array}$ & $\begin{array}{l}\text { дрвендечити се, дрвенити, дрвечити (се), } \\
\text { подрвенети (подрвењети), дрвенити се, } \\
\text { дрвити се, удрвити се, удрвенити се, } \\
\text { задрвенити се, здрвенити се, } \\
\text { одрвенити/одрвенети се (одрвењети се), } \\
\text { одрвочити се }\end{array}$ \\
&
\end{tabular}

3.4. ЖивотињЕ. Домену животиња припадају зооними. У случају суфиксираних номинација и у појединим сложеницама мотивни појам, односно именичка компонента, има функцију локализатора с ознаком простора у којем именована животиња (инсект) живи - дрвенар 'врста мрава који живи у шупљинама дрвета', дрвољуб 'врста инсекта, кукца тврдокрилца Dendrophilus', дрвуља 'врста инсекта Gasterocerus' или полаже јаја дрварица/дрвенара/дрвенарица 'врста осе'. Слична је мотивациона база и у сложеници дрволаз/дрволаж/дрволаш/дрвоплаз 'врста змије која пузи по дрвећу'.

Другој групи зоонима одговара трансформациони модел у којем лексема дрво има функцију објекта, а транзитивни глагол представља другу сложеничку компоненту (Ио + о Го + суфикс): точити - дрвоточац/дрвоточица 'породица лептира чије ларве буше ходнике у дрвету'; јести 'дупсти, гристи (о црву)' дрвојед/дрвоједач 'група малих корњаша, шумских штеточина'; ждерати дрвождер/дрвождерач ‘инсект који једе дрво’; гристи - дрвогриз 'врста инсекта тврдокрилца Luctus чије ларве нагризају дрво'; бушити - дрвобушач 'врста шкољке која буши дрво на бродовима'; морити 'уништавати' дрвомор/дрвомора/дрвомораи 'врста инсекта, тврдокрилца корњаша Ips 
typographus'. Овим називима означене су штеточине које припадају нижим животињским врстама.

Ретко се лексемом дрво, било у изведницама било у сложеничким образовањима, мотивишу називи других животиња, попут птица или риба. То су по правилу покрајинизми, кљујдрво 'велики детао', чија је мотивација прозирна (радња коју ова птица изводи на дрвету; она сатима може кљуцати дрво у потрази за храном) и дрвенаи 'бакалар', риба која бојом и својим изгледом подсећа на грану.

\begin{tabular}{|c|c|c|}
\hline $\begin{array}{l}\text { Активна } \\
\text { компонента из } \\
\text { семантичког } \\
\text { садржаја лексеме } \\
\text { дрво } \\
\end{array}$ & Семантички модел & Добијено именовање \\
\hline дрво као простор & $\begin{array}{l}\text { ‘онај чије је станиште у } \\
\text { дрвету’ } \\
\text { ‘онај који полаже јаја на } \\
\text { дрвету’ } \\
\text { ‘онај што се креће по } \\
\text { дрвету’ }\end{array}$ & $\begin{array}{l}\text { дрвенар, дрвољуб, дрвуља } \\
\text { дрварица, дрвенара, дрвенарица } \\
\text { дрволаз, дрволаж, дрволаш, } \\
\text { дрвоплаз }\end{array}$ \\
\hline $\begin{array}{l}\text { дрво као материја } \\
\text { (објекат) }\end{array}$ & $\begin{array}{l}\text { ‘онај што једе/ждере/гризе } \\
\text { дрво' } \\
\text { ‘онај што буши дрво' } \\
\text { 'онај што уништава дрво' }\end{array}$ & $\begin{array}{l}\text { дрвојед, дрвоједац; дрвождер, } \\
\text { дрвождерац; дрвогриз; кљујдрво } \\
\text { дрвобушац } \\
\text { дрвомор, дрвомора, дрвоморац }\end{array}$ \\
\hline боја & 'онај што има боју дрвета' & дрвенац \\
\hline
\end{tabular}

И у овој тематској групи су веома заступљени варијантни облици. Најпродуктивнији је суфикс -(a)u који се јавља у сложено-суфиксалним облицима, а његови конкуренти су -ф (дрвоједац и дрвојед; дрвождерац и дрвождер) сасвим по изузетку и -ица (дрвоточац и дрвоточища). Чести су и облици с фонолошким варијацијама (дрволаз/дрволаж/дрволаш/дрвоплаз). За једну врсту осе потврђена су три назива различитог деривационог статуса: другостепени деривати изарица изеден суфиксом -ица丿 $a^{11}$ и дрвенара с основом придева дрвен и суфиксом -ара и дериват трећега степена дрвенарица с основом деривата дрвенара и изведн суфиксом -иц̧а.

11 Дериват дрварица у зоонимском значењу може се одредити и као дериват првог степена, изведен суфиксом -арища. Међутим, ово значење је део полисемантичке структуре мовираног облика дрварица, те га стога приказујемо као дериват другог степена. 
3.5. ПРЕДМЕТИ. Именице с предметним значењем су претежно другостепени деривати с основом придева дрвен, који у њих преноси своје примарно градивно значење 'који је начињен од дрва, дрвета'. Семантички опсег деривата из ове категорије доста је широк. Креће се од збирног значења које је реализовано лексемама заст. дрвољ, покр. дрвор, дрварија ${ }^{12}$ и дрвенарија 'предмети од дрвета', покр. дрвуљан/дрвуљарија/дрвуљија 'дрвенарија', покр. дрвечија 'дрвена грађа (кочеви, летве, даске)' преко општег значења 'оно што је начињено од дрвета' у дериватима дрвењак 'оно што је начињено од дрвета: а. штап; б. мост; в. (обично у мн.) дрвена обућа' и дрвендор покр. 'дрвени део каквог предмета'. Семантичка конкретизација именица овога типа постиже се лексичким спајањем с именицама које су у функцији денотата, као у случају лексеме дрвењача у споју с именицама чаша или кашика. ${ }^{13}$

Делимично спецификовано значење остварено је у деривату дрвенина 'дрвени део кућног намештаја, дрвенарија', а са потпуном спецификацијом и одређеним денотатом јављају се суфиксали: дрвеница 'дрвени део самара', покр. дрвание 'дрвени суд за пиће', покр. дрвакиња 'пећ која троши много дрва', покр. дрвчаник 'попречна дрвена полуга на колима за коју се привезују конопци од хамова, ждрепчаник' и сложенице палидрвце ков. заст. 'шибица', дрвомер 'справа за мерење висине и дебљине дрвета'.

Овом домену припајамо и сложенице дрворез, дрвотисак и заст. дрвотис, те дериват дрворезина 'дрворез који служи као клише за штампање', ков. заст. дрвопис јер се оне могу схватити као опредмећени резултат радње. ${ }^{14}$

Са деривационог аспекта конкурентност испољавају суфикси заступљени у дериватима са збирним значењем: -арија (у споју са именичком основом) -ољ, -ор, и сложени суфикси (-yљљан, -уљарија, -уљија), и то све у покрајинизмима.

Већина ових именица има развијену семантичку структуру. Сва значења с предметном денотацијом добијена су метонимијом типа материјал $\rightarrow$ предмет начињен од тог материјала, и то у односу на реч дрво или придев дрвен, понављањем творбеног модела, а само поизузетку посредством метафоричне асоцијације када је у питању пренос именовања с предмета на човека (дрвењак).

\footnotetext{
12 У РСАНУ лексема дрварија има и секундарно значење 'експлоатација дрвета, снабдевање дрветом, дрварење'.

13 Лексема дрвењача има секундарне реализације 2. 'дрвена кућа, дрвењара'; 3. 'дрвена нога'; 4. инд. 'дрвна влаканца која се додају целулози у индустрији папира'.

14 Лексема дрворез има терминологизовано секундарно значење: граф. 'репродуковање и умножавање слика или цртежа помоћу дрвених плоча; тако добијена слика'.
} 


\begin{tabular}{|c|c|c|}
\hline $\begin{array}{l}\text { Активна } \\
\text { компонента из } \\
\text { семантичког } \\
\text { садржаја лексеме } \\
\text { дрво } \\
\end{array}$ & Семантички модел & Добијено именовање \\
\hline \multirow[t]{3}{*}{$\begin{array}{l}\text { материјал за } \\
\text { израду предмета }\end{array}$} & $\begin{array}{l}\text { ‘онај који је направљен од } \\
\text { дрвета' }\end{array}$ & $\begin{array}{l}\text { дрвени предмети уопште: дрвољ, } \\
\text { дрвор, дрварија, дрвенарија, } \\
\text { дрвуљан, дрвуљарија, дрвуљија, } \\
\text { дрвечија, дрвењак, дрвендор } \\
\text { посуђе и прибор за јело: дрвењача, } \\
\text { дрванце }\end{array}$ \\
\hline & & $\begin{array}{l}\text { дрвени део неког предмета: } \\
\text { дрвенина, дрвеница, дрвчаник }\end{array}$ \\
\hline & $\begin{array}{l}\text { 'опредмећени } \\
\text { радње' }\end{array}$ & $\begin{array}{l}\text { дрворез, дрвотисак, дрвотис, } \\
\text { дрворезина, дрвопис }\end{array}$ \\
\hline $\begin{array}{l}\text { димензије (обим и } \\
\text { висина }\end{array}$ & $\begin{array}{l}\text { 'справа за мерење висине } \\
\text { и дебљине дрвета' }\end{array}$ & дрвомер \\
\hline
\end{tabular}

3.6. ОсоБинЕ. У оквиру посматраног домена регистроване су јединице с граматичким значењем - посесивни придеви: нераспростр. дрветов, релациони придеви - необ. дрвећи, дрвни, деривати првог степена. По свом семантичко-деривационом потенцијалу издваја се придев дрвен, који развија богату деривациону мрежу захваљујући свом семантичком садржају. Посебну индуктивну моћ има његова секундарна реализација 3 . фиг. 'који је без живота, без осећања, укочен, крут'. Овим значењем мотивисани су апстрактуми дрвенило 'стање, особина особе која је укочена, безизражајна као да је дрвена, укочена' и дрвеност 'својство онога што је дрвено; фиг. неосетљивост, укрућеност, укоченост', одрвенелост (одрвењелост) 'стање онога који је одрвенео, онога што је одрвенело; фиг. духовна крутост, конзерватвност', као и код симилативних придева, деривата другог степена, у случају придева дрвењаст/дрвенаст 1. 'који је као од дрвета'; ${ }^{15}$. фиг. 'безосећајан, неосетљив; укочен, непокретан' док дериват дрвенкаст функционише као његов варијантни облик са суженим значењем 'дрвенаст (2)'. Апстрактум дрвенастост, означен као необичан, такође припада овом домену на основу реализације 'особина онога који је дрвенаст', као и прилог дрвењасто настао конверзијом и са значењем 'на дрвењаст начин, неспретно, круто'. И покрајинизам дрваст, првостепени дериват, има искључиво значење индуковано метафором, којим се именује

${ }^{15}$ У РСАНУ са истим значењем регистрована и лексема покр. дрвеничав. 
карактерна особина човека 'крут, задрт, тврдоглав'. Такви су и деривати мотивисани сложеницом дрвендека - квалитативни придев дрвендекаст ‘који је по природи дрвендек, који се односи на дрвендеке, неспретан' и прилог дрвендекасто 'као дрвендек, неспретно, неокретно', као и придевска сложеница дрвеноног 'који има дрвену ногу' и прилози у функцији квалификације одређеног стања или радње: одрвењено необ. 'као дрвен, укрућено'; дрвено 'попут дрвета, без живота, укочено, тврдо, неспретно'; дрвељасто 'дрвено'. Својеврсна особина изражена је и сложеним квалитативним придевом дрволик 'који је сличан дрвету (стабљика)'.

\begin{tabular}{|c|c|c|}
\hline $\begin{array}{l}\text { Активна } \\
\text { компонента из } \\
\text { семантичког } \\
\text { садржаја лексеме } \\
\text { дрво }\end{array}$ & Семантички модел & Добијено именовање \\
\hline $\begin{array}{l}\text { градивни } \\
\text { материјал }\end{array}$ & 'који је од дрвета' & дрвен, дрвеноног \\
\hline непокретност & $\begin{array}{l}\text { ‘који је непокретан као дрво’ } \\
\text { ‘који је неосетљив, крут, } \\
\text { укочен као дрво’ }\end{array}$ & $\begin{array}{l}\text { дрваст, одрвењено } \\
\text { дрвен, дрвенило, дрвеност, } \\
\text { одрвенелост (одрвењелост), } \\
\text { дрвењаст, дрвенаст, } \\
\text { дрвењасто, дрвено, дрвењасто, } \\
\text { дрвендека, дрвендекаст, } \\
\text { дрвендекасто }\end{array}$ \\
\hline изглед & ‘који је као дрво’ & дрволик, дрвљан \\
\hline
\end{tabular}

Са промењеним денотатом (не односи се на човека) регистрован је нераспрострањени квалитативни придев дрвљан 'који истерује, развија грану, лист (а не плод); на којем нема плода'.

3.7. Простор. Лексема дрво има значајну мотивациону улогу у деривацији именица с просторним значењем. У првом реду то су именице којима се означава место где се одлажу дрва, при чему је партонимска компонента мотивног појма у функцији индуктора деривације. Њихова семантичка структура је углавном двозначна, с примарном реализацијом 'место где се држе дрва' и подреализацијом 'складиште или стовариште дрва, продавница дрва'. У појединим дериватима или коегзистирају обе реализације, или се остварује само једна од њих. Суштински, њихова 
категоријална обележја се не разликују значајно (затворен наменски простор), те их стога приказујемо као јединствен лексички скуп.

Ове јединице имају изражене варијантне облике у чијој су деривацији заступљени различити суфикси, који међусобно функционишу као конкурентне форме. Са доминантним значењем 'место где се држе дрва' регистроване су јединице: дрвало, дрваница, дрвариште, дрварник, ${ }^{16}$ покр. дрвљаник, дрвљак, дрвљеник, дрвнара, покр. дрвник, дрвњак, дрвеник, а са значењем 'складиште или стовариште дрва, продавница дрва' посведочени су деривати дрвара и дрварница. Ови облици су изведени различитим суфиксима

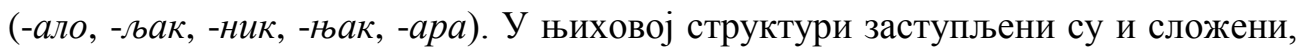
уланчани форманати

(-аница, -ариште, -арник, -љаник, -љеник, -нара, -еник, -арница). У деривационом систему регуларна је употреба већине наведених суфикса, док се поједини јављају у дијалектизмима (-љак, -ариште, -нара).

Сложеница дрвоцеn (дрвоијеn) својим примарним значењем 'место где се цепају дрва' уклапа се у посматрани домен, а њено секундарно значење настало под утицајем синегдохе гласи 'пањ, клада на којој се цепају дрва'.

Овом домену припадају и деривати дрвенара/дрвењара 'дрвена кућа', као и називи занатлијских радионица: дрводељница (дрводјељница) 'дрводељина радионица' и дрворезнища 'радионица у којој се израђују ствари изрезане у дрвету'. Ако се сложеница дрворед семантички интерпретира као 'место, односно пут или стаза оивичена посађеним дрвећем', као што је то у РСАНУ, онда и ова лексема припада посматраном појмовном домену.

Приказаним дериватима именује се отворени или затворени наменски простор, а лексема дрвосечина (дрвосјечина) 'део шуме који се сече или је одређен за сечу', као назив дела природног простора такође припада овом домену.

\footnotetext{
${ }^{16}$ У РСАНУ лексема дрварник има секундарно значење ‘део шуме одређен за сечу’.
} 


\begin{tabular}{|c|c|c|}
\hline $\begin{array}{l}\text { Активна } \\
\text { компонента из } \\
\text { семантичког } \\
\text { садржаја лексеме } \\
\text { дрво } \\
\end{array}$ & Семантички модел & Добијено именовање \\
\hline материја за огрев & $\begin{array}{l}\text { 'где се дрво одлаже, } \\
\text { складишти, продаје' }\end{array}$ & $\begin{array}{l}\text { дрвало, дрваница, дрвариште, } \\
\text { дрварник, дрвљаник, дрвљак, } \\
\text { дрвљеник, дрвнара, дрвник, дрвњак, } \\
\text { дрвеник; дрвара, дрварница; дрвоцеп } \\
\text { (дрвоцјеп) }\end{array}$ \\
\hline материја за обраду & $\begin{array}{l}\text { 'где се дрво обрађује и } \\
\text { користи у различите } \\
\text { сврхе' }\end{array}$ & $\begin{array}{l}\text { дрводељница } \\
\text { дрворезница }\end{array}$ \\
\hline $\begin{array}{l}\text { грађевинска } \\
\text { материја }\end{array}$ & $\begin{array}{l}\text { 'кућа саграђена } \\
\text { дрвета' }\end{array}$ & дрвенара, дрвењара \\
\hline
\end{tabular}

3.8. РЕЧИ СУБЈЕКТИВНЕ ОЦЕНЕ. Деривација именица с мотивном речју дрво којима се исказује субјективна оцена није нарочито плодна. То су деминутиви, првостепени деривати, варијантни облици, изведени различитим суфиксима: дрвенще, дрвешие и дрвашще, дрвка. Лексема дрвие, поред деминутивног значења, има следеће секундарне реализације засноване на синегдохи: 2. 'ситно исцепано дрво'; 3. 'шибица'. Овде припада и збирна именица дрвцад. РСАНУ бележи и необичан деминутивни облик дрвећище, с ознаком идивидуално, те лексему дрвица 'мање парче дрвета'. Варијантни облици деривата последица су употребе различитих суфикса с основном деминутивном функцијом: -енце, -ешще, -ашще, -ка, -ища.

\begin{tabular}{|c|c|c|}
\hline $\begin{array}{l}\text { Активна } \\
\text { компонента из } \\
\text { семантичког } \\
\text { садржаја лексеме } \\
\text { дрво }\end{array}$ & Семантички модел & Добијено именовање \\
\hline \multirow[t]{3}{*}{ величина } & ‘мало дрво’ & $\begin{array}{l}\text { дрвенце, дрвешце, дрвашце, дрвка, } \\
\text { дрвце, дрвцад, дрвећице }\end{array}$ \\
\hline & 'велико дрво’ & $\begin{array}{l}\text { дрветина, дрвина, дрворак, } \\
\text { дрвуљина, дрвурина }\end{array}$ \\
\hline & 'мање парче дрвета' & дрвица \\
\hline
\end{tabular}

Творба аугментатива је веома ниске продуктивности. У РМС је регистрован само један дериват дрветина изведен типичним аугметативним суфиксом -етина, а у РСАНУ и неуобичајени облик дрвина, покрајинизам дрворак, дрвуљина, дрвурина. У њиховој творби је заступљен суфикс -ина, те 
уланчани суфикси -уљина, -орак, -љика међу којима се успоставља конкурентни однос.

3.9. ГљивЕ. Гљиве се разликују од биљака и животиња и предствљају посебну групу организама. Сличност са животињама видљива је у њиховој номинацији односно семантичкој бази која је истоветна за неке инсекте. У РМС су посведочена само два сложеничка творбена дублета дрвојед и дрвојетка 'врста гљиве', а у РСАНУ и сложеница дрвоток са истим значењем. Прозирна је мотивација за сложеничко именовање гљиве дрвојед/двојетка/дрвоток. Она је опасна за дрвене грађевине јер њен мицелијум растаче дрво. ${ }^{17}$

\begin{tabular}{lll}
\hline $\begin{array}{l}\text { Активна компонента из } \\
\text { семантичког садржаја } \\
\text { лексеме дрво }\end{array}$ & Семантички модел & Добијено именовање \\
\hline дрво као материја (објекат) & $\begin{array}{l}\text { ‘оно што једе/растаче } \\
\text { дрво }\end{array}$ & дрвојед, двојетка, дрвоток \\
\hline
\end{tabular}

3.10. ОСТАЛИ дОМЕНИ. Домени репрезентовани малим бројем дривата или само једним дериватом значајни су јер употпуњују конпетуализацију стварности посредством појма дрво и његових деривата. То су следећи домени: НОВЧАНА НАДОКНАДА дрварина 1. 'новац за куповину дрва'; 2. 'Порез или такса за сечу дрва у шуми или као царинска пристојба за увоздрва'; ПИЋЕ дрвеника покр. 'врста вина', МЕРА дрвењка покр. заст. 'мера за жито (око 50 литара)'; СМЕСА дрвомаз заст. 'балега или смеса од говеђе балеге, пепела, лужне воде и др. за премазивање повређених места на воћкама или дрвећу уопште', БИљКА дрвац 'шимшир Buxus sempervirens'. Назив жбуна дрваи је с јасном мотивацијом - то је дрвенаста биљка, налик дрвету.

\section{4. ЗАКЉУЧАК}

У овом истраживању предмет рада представља лексема дрво са својим дериватима. Најпре су компоненцијалном анализом утврђене активне и

\footnotetext{
17 Она се појављује попут беле вате на површини влажне дрвене подлоге и излучује капљице воде као сузе, чиме је мотивисано њено латинско име lacrimans (који плаче) (http://www.enciklopedija.hr/natuknica.aspx?id=16356).
} 
продуктивне компоненте значења из мотивног појма које су у функцији индуктора како нових значења тако и нових лексичких јединица.

Доменом чОВЕК обухваћен је највећи број деривата. Језгро овог домена представљају агентивне именице у чијој појмовној вредности мотивни појам представља објекат манипулација различитог типа, што је уочљиво и код јединица које попуњавају такође продуктиван домен РАДњЕ И АКтивности. Атрибутивне именице настале под дејством метафоре индуковане су имплицитним компонентама непокретљивост, непомичност, тврдоћа заступљеним у појмовном садржају мотивне речи. Међу глаголским дериватима којима се изражава концепт сТАњА или ПОНАШАЊА човека активне су исте компоненте и исти трансформациони механизам. И деривати из домена ОсОБИНЕ настали су под дејством истоветних метафоричних асоцијација.

Извесна семантичка специфичност испољава се међу зоонимима. У њиховим називима мотивни појам има функцију локализатора или објекта који животиња уништава, чија је номинација мотивисана човековим искуством. Домену живОтињЕ припадају деривати којима се претежно именују ниже животињске врсте.

Будући да се дрво користи као материјал за израду различитих ПРЕДМЕТА, и овај домен садржи доста јединица с предметним значењем које се развија посредством метонимијског принципа. У њиховој деривацији значајан је придев дрвен и његово градивно значење.

Доменом ПРОСТОРА обухваћене су лексеме којима се именује наменски простор (за чување дрвета), кућа саграђена од дрвета или занатлијске радионице, при чему је номинација ових ентитета такође заснована на људском искуству и употреби дрвета као средства за огрев или грађевинског материјала.

Са мањим бројем представника су домени којима су обухваћена

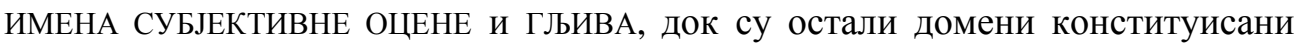
углавном на основу само једног деривата (НОВЧАНА НАДОКНАДА, ПИЋЕ, МЕРА, СМЕСА, БИљАКА). Појмовни домени указују на изразиту антропоцентричност, која се рефлектује и у лексикону, што је последица непосредног човековог искуства с именованим ентитетом - дрво као извор топлоте (које се као такво чува у наменском простору), дрво као материјал за израду различитих предмета (предмети), као и деривати с човеком као денотатом (занатлије и др.). 
На крају, формирање концепта зависи од средине, друштвених околности, степену материјалне културе, начину живота у одређеном времену, о чему сведоче бројни покрајинизми и архаизми, као и потврђене агентивне именице (дрвотржац, дрвоцепа), али називи посуђа и прибора за јело направљених од дрвета.

Gordana R. Štasni

\section{CONCEPTUAL VALUES OF THE LEXEME TREE AND ITS DERIVATIVES IN THE SERBIAN LANGUAGE}

\section{Summary}

On the basis of the lexical meaning of the lexeme tree and its derivatives, conceptual domains and ordered unities which are related to them are established. The lexeme tree has a polysemous structure, and its semantic-derivational network has over 200 derivatives excerpted from the Serbian dictionaries $R M S$ and $R S A N U$. In this research, componential and conceptual analysis are implemented. The analyses show that derivatives belong to different conceptual domains: MAN, PROPERTIES, ACTION AND STATE, TREE, ANIMALS, SPACE, OBJECTS with a larger number of representatives; and the domain of WORDS WITH SUBJECTIVE ASSESSMENTS (diminutives and augmentatives) and MUSHROOMS with a smaller number of derivatives and five domains that have only one unit: CASH, DRINK, MEASUR, MIX and PLANT.

On the level of derivational variant forms, especially dialectisms, it is shown that the same concept has different forms specific to a particular speech area. Derivational analyses also indicate a high potential of the adjective wooden which inducted further derivation. New derivatives motivated by the adjective wooden contain meaning related to building and the implicit components immobility and hardness contain it in their conceptual values. The metaphoric associations are in the base of these meanings and, as a rule, their denotatum is a man. In the case of $1^{\text {st }}$ derivational level (with the steam of the motivating word) different semantic processes are activated - metonymy and synecdoche.

Conceptual domains point to very pronounced anthropocentricity which is reflected in the Serbian lexical system. It is a consequence of man's experience with this entity - wood as a source of heat, wood as a material for making various objects (objects), as well as derivatives with the man as a denotatum (artisans, etc.).

Keywords: the lexeme tree, derivatives, conceptualisation, conceptual domain, Serbian. 


\section{ИЗВОРИ}

RMS - Rečnik srpskohrvatskoga književnog jezika (1967-1976). Novi Sad: Matica srpska. Zagreb: Matica hrvatska. (rečnik objavljen na ćirilici)

RSANU - Rečnik srpskohrvatskog književnog $i$ narodnog jezika. IV- (1966). Beograd: SANU - Institut za srpski jezik SANU. (rečnik objavljen na ćirilici)

\section{ЛИТЕРАТУРА}

Klajn, I. (2002). Tvorba reči u savremenom srpskom jeziku. Prvi deo - slaganje $i$ prefiksacija. Beograd - Novi Sad: Zavod za udžbenike i nastavna sredstva - Institut za srpski jezik SANU - Matica srpska. (knjiga objavljena na ćirilici)

Klajn, I. (2003). Tvorba reči u savremenom srpskom jeziku. Drugi deo - sufiksacija i konverzija. Beograd - Novi Sad: Zavod za udžbenike i nastavna sredstva Institut za srpski jezik SANU - Matica srpska. (knjiga objavljena na ćirilici)

Lyons, J. (1995). Linguistic semantics: An introduction. Cambridge: Cambridge University Press.

Leech, G. (1983). Semantics. Harmondsworth: Penguin Ltd.

Skok, P. (1971). Etimologijski rječnik hrvatskoga ili srpskoga jezika. Zagreb: Jugoslavenska akademija znanosti i umjetnosti.

Štrbac, G.-Štasni, G. (2017). Somatizmi i konceptualizacija stvarnosti u srpskom jeziku (glava $i$ njeni delovi). Novi Sad: Filozofski fakultet. (knjiga objavljena na ćirilici) 